Komunike, Volume XII, No. 2 Desember 2020

\title{
INOVASI DAKWAH PERGURUAN TINGGI (Studi Naratif pada Universitas Negeri Semarang)
}

\author{
Vitradesie Noekent \\ Fakultas Ekonomi - Universitas Negeri Semarang \\ Kampus Unnes Sekaran, Gunungpati, Semarang. 50229. \\ vitradesienoekent@mail.unnes.ac.id
}

\author{
Andri Kurniawan \\ Fakultas Dakwah dan Ilmu Komunikasi \\ Universitas Islam Negeri Mataram \\ andrikurniawan@uinmataram.ac.id
}

\begin{abstract}
Innovation of da'wah in higher education serves the heart of a successful balance of academic achievement and the nobility of the academic community. This study aims to narrate the innovation of da'wah at the Universitas Negeri Semarang within the framework of da'wah management theory that prioritizes a contingency approach in creating a harmony of preaching and academic activities. The research method used was a narrative study of three key figures who created the da'wah ecosystem at Universitas Negeri Semarang. The results showed that the enthusiasm for preaching has gained momentum since the strengthening of the role and physics of mosques in all faculties in Universitas Negeri Semarang. The existence of the mosque gave birth to prominent figures, created a routine of preaching moderation, as well as eliminating the seeds of radicalism and intolerance in the campus environment. Furthermore, authors also provide suggestions for higher education leaders and the government (Kemendikbud) as the regulator of higher education in Indonesia.
\end{abstract}

Keywords: innovation of da'wah, contingency approach, narrative study. 
Komunike, Volume XII, No. 2 Desember 2020

\begin{abstract}
Abstrak
Inovasi dakwah di perguruan tinggi menjadi nyawa keseimbangan sukses prestasi akademik dan keluhuran budi pekerti sivitas akademikanya. Kajian ini bertujuan menarasikan inovasi dakwah pada Universitas Negeri Semarang dalam bingkai teori manajemen dakwah yang mengutamakan pendekatan kontingensi dalam menciptakan harmoni aktivitas dakwah dan akademik. Metode penelitian yang digunakan adalah studi naratif terhadap tiga tokoh kunci yang turut membangun ekosistem dakwah di Universitas Negeri Semarang. Hasil penelitian menunjukkan bahwa ghirah atas dakwah mendapatkan momentumnya semenjak diperkokohnya peran dan fisik masjid di semua fakultas di lingkungan Universitas Negeri Semarang. Keberadaan masjid melahirkan tokoh-tokoh penggerak, menciptakan rutinitas dakwah moderasi, juga mengelininasi bibit radikalisme dan intolerasi di lingkungan kampus. Lebih lanjut, peneliti turut menyampaikan saran bagi pimpinan perguruan tinggi dan pemerintah (Kemendikbud) sebagai regulator pendidikan tinggi di Indonesia.
\end{abstract}

Kata Kunci: inovasi dakwah, pendekatan kontingensi, studi naratif. 
Komunike, Volume XII, No. 2 Desember 2020

\section{A. PENDAHULUAN}

UU Nomor 12 tahun 2012 tentang pendidikan tinggi mengamanatkan kepada pemerintah untuk mengusahakan dan menyelenggarakan satu sistem pendidikan nasional yang meningkatkan keimanan, ketakwaan kepada Tuhan Yang Maha Esa, dan akhlak mulia dalam rangka mencerdaskan kehidupan bangsa serta memajukan ilmu pengetahuan dan teknologi dengan menjunjung tinggi nilai-nilai agama dan persatuan bangsa untuk kemajuan peradaban serta kesejahteraan umat manusia. Kementerian Pendidikan dan Kebudayaan yang merupakan representasi pemerintah, menyelenggarakan pendidikan tinggi di Indonesia dalam bentuk perguruan tinggi dengan status universitas, institut, sekolah tinggi, politeknik, dan sejenisnya. Berdasarkan amanat UU Nomor 12 tahun 2012, perguruan tinggi berkewajiban menyediakan ekosistem yang menciptakan keseimbangan pencapaian prestasi akademik dan keluhuran budi pekerti sivitas akademika yang terlibat di dalamnya.
Berkaitan

dengan

keseimbangan prestasi dan keindahan moral, penulis mengidentifikasi setidaknya tiga tantangan yang dihadapi perguruan tinggi di abad ke21 ini. Pertama, terjadinya dikotomi ilmu agama, termasuk didalamnya Ilmu Dakwah, dengan perkembangan ilmu pengetahuan dan teknologi hingga mengakibatkan jurang persepsi antara dunia dan akhirat, antara pasar dan masjid, dan tentu saja antara ilmu agama dan ilmu umum/dunia. Di sisi lainnya, dalam mensikapi kompleksitas dan ambiguitas fenomena masyarakat, perguruan tinggi diharapkan dapat menjadi sumber solusi komprehensif terhadap beragam persoalan sosialkeagamaan, sosial-ekonomi, sosialbudaya, hukum dan politik.

Kedua, kampus sebagai pusat pembelajaran generasi muda menjadi tempat yang paling diincar kelompok radikal intoleran untuk menyebarkan ideologinya. Menurut Badan Nasional Penanggulangan Teroris (BNPT), potensi radikalisme di 
Komunike, Volume XII, No. 2 Desember 2020

perguruan tinggi yang mengarah teroris secara nasional sebesar $39 \% 1$.

Ketiga, dominasi teori-teori "Barat" pada perguruan tinggi di Indonesia. Padahal, menurut Rahwar dan Al-Buraey dalam ${ }^{2}$, teori organisasi Barat tidak mudah disandingkan dengan budaya Islam di beberapa negara di Jazirah Arab karena terfokus pada sikap individualistis dan diukur dengan pendekatan ekonomi. Model manajemen barat menunjukkan bahwa banyak individu yang mengabaikan kebutuhan rohani dalam pekerjaan hingga fenomena sekulerisme. Bjork dan Al-Meer dalam $^{3}$ melakukan investigasi budaya bisnis Arab dalam program teaching business subjects dengan menggunakan American Management Textbooks dan menemukan perbedaan yang signifikan dalam budaya bisnis sehingga menyimpulkan bahwa “...western theories of work motivation and work values may also

\footnotetext{
${ }^{1}$ Extra News, "BNPT Road Show Ke Poltek Sriwijaya", dalam https://extranews.id/2019/10/ 01/bnpt-roadshow-ke-poltek-sriwijaya-cegahradikalisme/ (23 November 2020).
}

be inappropriate for Islamic countries." (...teori barat tentang motivasi kerja dan nilai kerja nampak bertentangan dengan budaya Islam).

Berdasarkan tiga tantangan perguruan tinggi dalam mewujudkan ekosistem keberhasilan dunia dan akhirat sebagaimana dipaparkan paragraf sebelumnya maka kajian ini berupaya menjawab tantangan dengan cara menginvestigasi manajemen dakwah di perguruan tinggi dengan menarasikan pengalaman unik dan spesifik Universitas Negeri Semarang (Unnes). Dua pertanyaan penelitian yang hendak dijawab adalah 1) manakala atau kapan dakwah di Unnes mulai menunjukkan ghirah/semangat? 2) Apa bentuk inovasi dakwah yang menonjol atau membedakan dengan dakwah di perguruan tinggi lain? Secara sistematis, kajian ini akan mendiskusikan manajemen dakwah, relasi manajemen dakwah dan sains sosial, pendekatan kontingensi dalam

2 I. Rahmat, The Celestial Management: Ikhtiar Mewujudkan Budaya Organisasi Islam. Jurnal MD, Vol. 2 No. 1(2016).

${ }^{3}$ Ibid. 
manajemen dakwah. Kajian ini juga mengkombinasikan maraji' dan teori manajemen untuk kemudian dipadukan menjadi bahan yang penting untuk didiskusikan bersama.

\section{B. TINJAUAN PUSTAKA}

Penting untuk penulis paparkan penelitian terdahulu (literature review) sebagai tolok ukur penelitian sekaligus memperkuat originalitas temuan, bahwa terdapat beberapa penelitian yang semisal dengan tema ini yaitu, penelitian pertama oleh Masayu Mashita Maisarah dengan judul penelitian "Aktualisasi Perguruan Tinggi Agama Islam Dalam Konteks Dakwah: Suatu Kajian Historis"4 menegaskan bahwa Institut Agama Islam Negeri (UIN/IAIN) merupakan Lembaga Pendidikan sekaligus Lembaga dakwah. Penelitian ini membantah pendapat yang menyatakan bahwa lunturnya nilai ke-Islaman UIN sebab transformasi IAIN ke UIN, justru membantu dalam memperkaya

4 Masayu Mashita Maisarah, "Aktualisasi Perguruan Tinggi Agama Islam Dalam Konteks Dakwah: Suatu kajian Historis", Jurnal AL-HUDA, Vol. 9 (2017), hlmn. 7190 pemahaman tentang ke-Islaman dan keilmuan lainnya. Dakwah di perguruan tinggi dimaksudkan untuk menyeru kalangan akademisi ke jalan Islam dengan berbasis temuan ilmiah atau riset. Karenanya, terdapat persamaan dalam penelitian ini dalam mengobservasi perguruan tinggi sebagai laboratorium dakwah. Selain itu, penelitian ini memiliki perbedaan yaitu penelitian oleh Masayu lebih cenderung melihat fungsi dakwah setelah transofrmasi dari IAIN ke UIN sedangkan penelitian ini lebih terfokus pada inovasi dakwah di perguruan tinggi dengan menggunakan teori manajemen dakwah dan pendekatan kontingensi.

Penelitian kedua oleh Siti Maisaroh dengan judul penelitian "Dakwah Kultural Perguruan Tinggi Islam pada Mahasiswa Nonmuslim (Studi: Sekolah Tinggi Ilmu Ekonomi (STIE) Yapis Merauke". 5 Penelitian dengan pendekatan kualitatif ini mendeskripsikan kebijakan kampus atau perguruan tinggi terhadap

\footnotetext{
5 Siti Maisaroh, "Dakwah Kultural Perguruan Tinggi Islam Pada Mahasiswa Nonmuslim (Studi: Sekolah Tinggi Ilmu Ekonomi (STIE) Yapis Merauke", (Tesis, Pascasarjana UIN Sunan Kalijaga, Yogyakarta, 2019), hlmn. 541-156.
} 
Komunike, Volume XII, No. 2 Desember 2020

mahasiswa nonmuslim dalam hal atribut dan fasilitas keagamaan, dan penerapan dakwah kultural perguruan tinggi terhadap mahasiswa nonmuslim. Persamaan dan perbedaan penelitian juga tentu ada. Persamaannya adalah fokus temuan penelitian Maisaroh menjelaskan dakwah yang masih dalam dimensi perguruan tinggi. Adapun perbedaannya, dalam penelitian ini lebih kepada bagaimana upaya membangun harominsasi dakwah dan akademik melalui Inovasi dakwah di perguruan tinggi sebagai keseimbangan prestasi akademik dan keluhuran budi pekerti sivitas akademika perguruan tinggi, sedangkan pada literature review lebih terhadap kebijakan kampus terkait dakwah kultural kepada mahasiswa nonmuslim.

Penelitian ketiga oleh Asep Iwan Setiawan dengan judul penelitian "Efektivitas Dakwah Fi'ah: Studi Model Dakwah Pada Lembaga Dakwah Kampus".6 Penelitian ini menemukan efektifitas dakwah fi'ah

${ }^{6}$ Asep Iwan Setiawan, "Efektivitas Dakwah Fi'ah: Studi Model Dakwah Pada Lembaga Dakwah Kampus", Jurnal Ilmu Dakwah,

Vol. 5 No. 2 (Juli - Desember, 2011), hlm. 574
Lembaga dakwah kampus melalui metode survei verifikatif menunjukkan dapat meningkatkan perilaku keagamaan mahasiswa dengan kualifikasi sangat baik yang dilakukan di perguruan tinggi negeri se-Kota Bandung, Jawa Barat. Penelitian ini memiliki persamaan objek penelitian berupa dakwah internal di perguruan tinggi namun perbedaan kontras adalah ruang lingkup penelitian yang menunjukkan riset kuantitatif pada perguruan tinggi se-Kota Bandung sedangkan penelitian ini bersifat kualitatif dengan setting penelitian di kampus tertentu yaitu Universitas Negeri Semarang.

\section{METODE PENELITIAN}

Guna menjawab tantangan dakwah perguruan tinggi sebagaimana dirumuskan dalam pertanyaan penelitian, penulis menginvestigasi praktik baik manajemen dakwah di Unnes. Untuk itu, desain penelitian yang sesuai adalah jenis penelitian yang menggunakan latar alamiah dengan 
maksud menafsirkan fenomena yang terjadi dengan jalan melibatkan berbagai metode yang saling menguatkan $^{7}$. Penelitian kualitatif merupakan tradisi ilmu pengetahuan sosial yang secara fundamental bergantung dari pengamatan pada manusia baik dalam kawasannya maupun peristilahannya ${ }^{8}$. Teknik pengumpulan data dilakukan dengan metode wawancara secara daring, observasi partisipatif, dan studi kepustakaan. Teknik dokumentasi dengan cara mengkoleksi informasi terkait berupa hal-hal atau variabel yang menjelaskan tentang isi penelitian juga dilakukan dengan tujuan triangulasi sumber data.

Selanjutnya, Pinnegar dan Daynes dalam ${ }^{9}$ mengemukakan bahwa yang dimaksud dengan studi naratif adalah studi yang menyajikan cerita atau pengalaman hidup seseorang atau bisa juga dimaknai sebagai studi terhadap suatu fenomena. Lebih lanjut, Czarniawska dalam Creswell (2007) menyatakan

7 Denzin \& Lincoln, The qualitative inquiry reader. Sage. (2002).

8 Kirk, J., Miller, M. L., \& Miller, M. L. Reliability and validity in qualitative research, Vol. 1, . Sage (1986). bahwa studi naratif merupakan studi tentang suatu kejadian atau rangkaian kegiatan atau kronologi kejadian. Dengan demikian dapat dikatakan bahwa studi naratif adalah studi yang mendeskripsikan pengalaman hidup seseorang atau organisasi ataupun kronologi suatu kejadian yang unik. Studi naratif kajian ini bertujuan menemukan pendekatan kontingensi dakwah kontekstual di perguruan tinggi (Unnes).

Adapun tahapan studi naratif yang dilakukan terbagi menjadi lima, yaitu:

1. memfokuskan diri pada masalah/ kejadian/ fenomena/ pengalaman hidup yang "unik" dan memastikan bahwa permasalahan tersebut paling sesuai jika diteliti dengan menggunakan studi naratif dan dilanjutkan pertanyaan penelitian;

2. menentukan satu atau beberapa orang yang mengalami hal tersebut;

9 Cresswell, Qualitative Inquiry and Research Design: Choosing Among Five Traditions. 2nd ed., Sage, Thousand Oaks, CA, (2007).

Vitradesie dan Andri Kurniawan 193 
Komunike, Volume XII, No. 2 Desember 2020

3. mengumpulkan dan merekam informasi atau cerita pengalaman hidup dari satu atau beberapa orang terpilih;

4. menganalisis dan menceritakan kembali proses kegiatan mengorganisasi kembali cerita yang telah diperoleh dan menuliskannya dalam urutan kejadian atau kronologi;

5. melakukan kolaborasi dengan partisipan dan melibatkanya secara aktif dalam penelitian/ studi yang sedang dilaksanakan. Kolaborasi ini dimaksudkan agar tidak terjadi perbedaan pemahaman/ pemaknaan pada cerita atau pengalaman hidup partisipan.

\section{HASIL DAN PEMBAHASAN}

Kata dakwah secara bahasa berasal dari kata kerja $d a$ ' $a, y a d^{\prime} u$, da'watan, yang berarti memanggil, mengundang, mengajak, menyeru, dan mendorong. Dakwah adalah aktivitas internalisasi dan sosialisasi nilai dengan menggunakan komunikasi lisan, tulisan dan keteladanan yang dilakukan dengan sistematis dan terencana dalam upaya

mempengaruhi individu (fardiyah) dan kelompok atau masyarakat (jama'iyah) untuk menumbuhkan suatu pengertian (kognitif), kesadaran (afektif), dan tindakan (psikomotor) untuk melaksanakan programprogram pengembangan masyarakat Islam. Ilmu Dakwah adalah suatu ilmu yang membahas tentang proses terjadinya upaya sosialisi dan internalisasi nilai dari $d a{ }^{\prime} i$ kepada mad'u untuk mencapai tujuan dakwah. Hukum berdakwah adalah wajib 'ain bagi setiap individu sesuai kemampuan. Oleh karena itu, pada hakikatnya, tujuan dakwah adalah untuk membentuk pribadi mad'u menjadi $d a$ ' $i$ dengan berbagai kompetensi intelektual dan spritual, $d a^{\prime} i$ pertama adalah Allah pencipta semesta.

Dakwah pada hakikatnya mengajak dan menyeru umat Islam menuju pedoman hidup yang di ridhai Allah Ta'ala dalam bentuk amar ma'ruf nahi munkar. Dakwah merangkum proses "penyadaran" manusia dari kehidupan kegelapan menuju kehidupan yang diridhai oleh Allah Ta'âlâ. Dakwah juga bermakna perjalanan "hijrah" dari keburukan 
menuju kebaikan. Dakwah mensyaratkan manajemen yang profesional guna memastikan dakwah yang disampaikan dapat diterima langsung oleh masyarakat (mad`u), menghasilkan perubahan dan meningkatkan efektifitas dakwah. Karenanya, penting untuk memaksimalkan fungsi manajemen dakwah agar kegiatan dakwah dapat berjalan sebagaimana mestinya. Hakikatnya, manajemen dakwah merupakan pengaturan sistematis dan koordinatif atas aktifitas dakwah yang meliputi perencanaan, pengelolaan, pengkoordinasian, dan pengevaluasian dakwah.

Dakwah Islam tidak hanya terbatas pada ceramah, khuthbah dan tabligh, akan tetapi lebih dari itu. Dakwah mencakup da'wah bil-lisan, da'wah bil kitabah dan da'wah bil hal. Ketiga bentuk dakwah ini telah dipraktikkan Rasulullah Muhammad SAW selama berdakwah Mekkah dan Madinah.

\section{Da'wah bil-lisan adalah} dakwah yang disampaikan melalui komunikasi lisan, seperti ceramah, pidato dan khuthbah. Ditinjau dari aspek penggunaan media, terdapat dua bentuk komunikasi. Pertama, komunikasi primer yaitu bentuk komunikasi yang disampaikan secara langsung melalui tatap muka tanpa media penghubung. Kedua, komunikasi sekunder, yaitu komunikasi yang menggunakan saluran media luar jaringan maupun media dalam jaringan. Da'wah billisan dapat disampaikan lewat komunikasi antar pribadi (da'wah fardiyah) dan bisa juga dalam bentuk komunikasi kelompok dan komunikasi massa (da'wah jama'ah). Da'wah fardiyah lebih populer dengan istilah al-Irsyad (dakwah konseling). Komunikasi interaktif di media sosial adalah bentuk yang paling populer saat ini untuk komunikasi penyiaran Islam. Teknologi informasi dan komunikasi (TIK), teori psikologi dan ilmu komunikasi sangat berperan mendifusikan da'wah bil-lisan .

Da'wah bil-kitabah adalah dakwah yang disampaikan dengan komunikasi tulisan. Bentuk ini dipergunakan Nabi Muhammad SAW untuk mengajak raja dan para pemimpin beberapa negara agar memeluk agama Islam. Sedikitnya 
Komunike, Volume XII, No. 2 Desember 2020

ada delapan surat yang dikirimkan Rasulullah kepada kepala negara yang berisi seruan memeluk agama Islam. Komunikasi dengan tulisan dikembangkan dengan bantuan teori-teori jurnalistik. Da'wah bil kitabah dapat berbentuk tulisan-tulisan ilmiah, sastra atau bunga rampai yang dimuat dalam jurnal, buku, majalah, surat kabar dan buletin. Salah satu kelebihan da'wah bil-kitabah ialah jangkauan tulisan yang luas dan kurun waktu yang relatif lama. Sebagai contoh adalah kitab-kitab klasik yang ditulis oleh para ulama terkemuka dalam tafsir, hadis, fiqih dan akidah, masih dapat ditemukan hingga saat ini.

Da'wah bil-hal merupakan dakwah keteladanan dalam bentuk perbuatan baik dan mulia. Perbuatan tersebut dapat berbentuk amal ibadah, aktivitas keagamaan maupun aktivitas sehari- hari. Da'wah bil-hal dimaknai sebagai perilaku baik, akhlak mulia, dan aktivitas keteladanan yang sesuai dengan petunjuk al-Quran dan Sunnah. Da'wah bil-hal bermakna luas, menyangkut segala aktivitas yang dapat meningkatkan kualitas kehidupan, baik kehidupan beragama, mengelola pendidikan, mengatasi kemiskinan, menjaga kesehatan dan kesejahteraan, penegakan hukum dan penguatan kerukunan umat. Rasulullah SAW telah menerapkan da'wah bil-hal dalam waktu 23 tahun dan sukses meletakkan dasardasar pembentukan peradaban masyarakat Islam yang besar di Madinah. Da'wah bil hal dapat diterapkan secara individu atau kelompok, komunitas, organisasi, instansi, atau lembaga. Da'wah bilhal yang dikenal juga dengan istilah da'wah harakah membutuhkan teori ilmu manajemen dalam pelaksanaan program-program pemberdayaan masyarakat.

\section{Relasi Dakwah dan Sosial Sains}

Ilmu Dakwah dan Ilmu Sosial memiliki objek kajian yang identik, yaitu manusia. Perilaku keagamaan da'i dan mad'u merupakan objek material Ilmu Dakwah. Karenanya, dalam mengkaji manusia dan kaitannya dengan perilaku sosial, perilaku budaya, hukum, ekonomi dan politik, Ilmu Dakwah tidak terisahkan dari kajian-kajian sains 
Komunike, Volume XII, No. 2 Desember 2020

sosial. Dalam menganalisa perilaku manusia, Ilmu Dakwah dapat menggunakan metode sains sosial untuk pengembangan keilmuannya. Al Quran menjelaskan bahwa manusia adalah makhluk sosial (an-Naas), sebagai makhluk biologis (al-Basyar) yang memiliki kebutuhan materil (ekonomi), makhluk psikologis (al-Insu) yang diberi potensi akal, kalbu dan nurani, juga sebagai makhluk yang berbudaya (bani Adam). Allah SWT mewajibkan manusia supaya berkomunikasi dengan-Nya (hablum min Allah) dan supaya berkomunikasi dengan sesama (hablum min anNaas). Berkaitan dengan kajian tentang manusia sebagai makhluk berbudaya, Ilmu Dakwah beririsan dengan Antropologi. Manusia terdiri dari berbagai ras, suku dan etnis, Ilmu Dakwah membutuhkan etnografi dan ilmu lain sejenisnya.

Di sisi lain al-Quran juga menyeru manusia untuk membaca, mengamati dan meneliti alam semesta termasuk dirinya sendiri. Karenanya, Ilmu Dakwah harus mengutamakan riset- riset empiris, baik dengan pendekatan kualitatif maupun kuantitatif. Penerapan sains sosial dalam kajian dakwah sangat membantu efektivitas dakwah. Misalnya penyiaran Islam melalui khuthbah atau tabligh, dapat menggunakan teori Ilmu Komunikasi, teori dakwah bimbingan konseling dengan teori psikologi, teori dakwah kelembagaan dengan teori Ilmu Manajemen, teori dakwah partisipatif dengan teori sosiologi, kajian tentang dakwah struktural menggunakan teori ilmu politik. Dengan bantuan ilmuilmu sosial, peran dakwah Islam semakin besar dan efektif dalam membentuk pribadi individu, keluarga, masyarakat dan bangsa. Psikologi Dakwah berperan memberikan bimbingan konseling persoalan-persoalan individu dan keluarga. Sosiologi diterapkan dalam menghadapi persoalan pembangunan masyarakat. Adapun Ilmu Ekonomi dipergunakan dalam masalah keterbelakangan dan kemiskinan serta meningkatkan daya saing umat. 
Komunike, Volume XII, No. 2 Desember 2020

\section{Pendekatan Kontingensi dalam Dakwah}

$$
\text { Pendekatan kontingensi }
$$

dalam Ilmu Dakwah terinspirasi

\section{Teori Kontingensi Kepemimpinan}

Fiedler (1967). Menurut Fiedler (1967) dalam ${ }^{10}$, kepemimpinan merupakan proses di mana kemampuan seorang pemimpin untuk mempengaruhi tergantung dengan situasi tugas kelompok (group task situation) dan tingkatan kelompok dari pada gaya kepemimpinan, kepribadian dan pendekatan pemimpin yang sesuai dengan kelompoknya. Artinya, seseorang menjadi pemimpin bukan karena kepribadiannya, namun karena berbagai faktor situasi dan adanya interaksi antara pemimpin dan situasinya. Tinggi rendahnya prestasi kerja satu kelompok dipengaruhi oleh sistem motivasi dari pemimpin dan sejauh mana pemimpin dapat mengendalikan dan mempengaruhi suatu situasi tertentu. Karenanya,

${ }^{10}$ Peters, L. H., Hartke, D. D., \& Pohlmann, J. T. Fiedler's Contingency Theory of Leadership: An application of the metaanalysis procedures of Schmidt and Hunter. Psychological bulletin, 97(2), (1985), hlm. 274. pendekatan kontingensi juga disebut sebagai pendekatan situasional.

Selanjutnya, ilmu manajemen memberikan definisi yang saling melengkapi untuk mendeskrisikan pendekatan kontingensi. Pendekatan kontingensi merupakan pendekatan manajemen yang mempercayai bahwa setiap organisasi bersifat unik, menghadapi situasi-situasi yang berlainan sehingga membutuhkan strategi pengelolaan yang berbedabeda $^{11}$. Perilaku manajerial yang sesuai dalam suatu situasi tertentu bergantung pada, atau kontingen terhadap, elemen unik dari situasi tersebut $^{12}$. Perluasan perspektif humanistik yang memandang keberhasilan penyelesaian masalahmasalah organisasi bergantung kepada pengenalan manajer akan variasi-variasi penting dari situasi yang dihadapi ${ }^{13}$. Keyakinan mendasar pendekatan kontingensi adalah perilaku pemimpin yang efektif pada

\footnotetext{
${ }^{11}$ Robbins, S. P., Stuart-Kotze, R., \& Coulter, M. Management. Scarborough, Ont.: Prentice Hall Canada, (2000).

12 Griffin, R. W. Management. Nelson Education. (2016).

13 Daft, R. L. Management. South-Western Cangage Learning. (2014).
} 
Komunike, Volume XII, No. 2 Desember 2020

situasi tertentu belum tentu efektif dalam situasi lainnya. Pada konteks selanjutnya, akan tercipta pola-pola keberagamaan (Islam) sesuai dengan konteks lokalnya.

Berdasarkan serangkaian penjelasan ini maka dapat dirangkum dua arti penting pendekatan kontingensi bagi Ilmu Dakwah. Pertama, karena tujuan dakwah adalah untuk membentuk pribadi mad'u menjadi $d a$ ' $i$ dengan beragam kompetensi intelektual dan spiritual, maka dibutuhkan pemahaman keperilakuan mad'u yang didasarkan pada ilmu sains sosial. Kedua, interaksi sosial antara mad'u dan lingkungannya merupakan

\section{Inovasi Dakwah pada Universitas Negeri Semarang}

Sebelum menjadi universitas pada tahun 2000, Unnes berstatus sebagai Institut Keguruan dan Ilmu Pendidikan (IKIP) Negeri Semarang yang berdiri sejak tahun 1965 di Kota Semarang. Pada tahun 2019, Unnes menetapkan visinya menjadi universitas berwawasan konservasi

${ }^{14}$ Peranan masjid sebagai pusat peribadatan dan peradaban Islam memiliki manfaat yang universal termasuk dalam konteks dakwah Islamiah berdasarkan nilai-nilai washatiyah. dan bereputasi internasional. Berwawasan konservasi bermakna cara pandang dan sikap perilaku yang berorientasi pada prinsip konservasi (pengawetan, pemeliharaan, penjagaan, pelestarian, dan pengembangan) sumber daya alam dan nilai-nilai sosial budaya. Prinsip tersebut menjadi landasan dalam kegiatan tri dharma perguruan tinggi. Adapun bereputasi internasional bermakna universitas yang memiliki citra dan nama baik dalam pergaulan internasional serta menjadi rujukan dalam kegiatan tridarma perguruan tinggi di tingkat internasional.

Momentum peningkatan ghirah dakwah di Unnes setidaknya terjadi pada saat pimpinan Unnes menginisiasi penguatan masjid yang berlokasi di delapan fakultas dan pasca sarjana. ${ }^{14}$ Selain memperbaiki infrastruktur masjid, pimpinan Unnes baik di tingkat universitas maupun fakultas membentuk struktur takmir masjid menjadi bagian dari kegiatan Tri Dharma Dosen. Adanya pengakuan secara formal materiil

Andri Kurniawan, "Peran Masjid Sebagai Sentra Dakwah Moderasi”, Jurnal Komunikasi Islam, Vol. 10 No. 1 ( Juni, 2020), hlm. 142. 
Komunike, Volume XII, No. 2 Desember 2020

menjadikan dosen, tenaga kependidikan, mahasiswa, bahkan alumni dan masyarakat sekitar menjadi bersemangat menghidupkan masjid melalui beragam kegiatan.

...menurut perkiraan saya mulai dimilikinya tempat ibadah (mushola/masjid) di masingmasing fakultas/unit kerja. Di samping itu, ghirah ini dirasakan sejak kegiatan keagamaan menjadi salah satu acara di Dies Natalis UNNES. Saya tidak tahu persis mulai kapan dalam arti tahun berapa. Tetapi sejak Dies menampilkan acara: UNNES Bersholawat, UNNES Berdzikir, Khataman Al Qur'an, dan sebagainya sangat saya rasakan semangat dakwah di UNNES (Mkho-W).

Beragam kegiatan yang memadukan unsur akademik (yaitu Dies Natalis Unnes) dan religius (misal: khataman Qur'an, shalawat) menjadi upaya pimpinan Unnes dan para penggiat kegiatan dakwah Unnes untuk mengintegrasi dan menginterkoneksikan ilmu (islamiyah al-ma'rifah). Upaya tersebut ditempuh melalui tarabuth al-ilmi yaitu saling keterkaitan antara ilmu Islam dengan ilmu umum, dan izdiwaj al-ilmi atau mengkombinasikan ilmu Islam dengan ilmu umum. 
komplek dan multidimensi, dalam berbagai aspek dan levelnya, membutuhkan keragaman disiplin ilmu guna memahami kompleksitas dimensi hidup manusia, bukan untuk menciptakan dikotomi. Hukum kausalitas adalah sunnatullah dalam qudrad dan irodat Sang Pencipta Yang Maha Esa.

Kodrat manusia adalah multi etnik, suku, budaya dan agama, keragaman sering menimbulkan konflik yang mengancam integrasi bangsa. Integrasi Ilmu Dakwah berusaha melakukan penyadaran sosial bahwa ranah Ilmu Dakwah dan Ilmu Sosial, memiliki signifikansi, apabila dibaca tarabuth dan izdiwaj menghasilkan pembacaan holistik yang berguna bagi peradaban.

Ilmu, iman dan amal dalam alQuran memasuki ranah kognitif, afektif dan psikomotor. Ilmu Dakwah integratif sebagaimana ditemukan pada praktik baik inovasi dakwah di lingkungan Unnes dimaksudkan sebagai upaya internalisasi nilai melalui ketiga ranah tersebut. Konsep nafs dalam al-Quran

\footnotetext{
${ }^{15}$ Kementeriaan Agama RI, Al-Qur'an Al-
} Karim dan Terjemahnya, hlm. 281. diintegrasikan dengan psikologi untuk menemukan inovasi dakwah yang sesuai dengan situasi mad'u.

Bersinggungan dengan hal ini, sebuah ayat merangkum trilogi diksi di atas yaitu surat An-Nahl ayat 125 yang berbunyi:

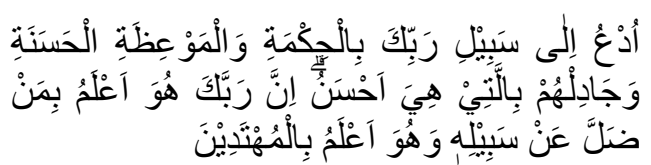

"Serulah (manusia) kepada jalan Tuhanmu dengan hikmah dan pengajaran yang baik, dan berdebatlah dengan mereka dengan cara yang baik. Sesungguhnya Tuhanmu, Dialah yang lebih mengetahui siapa yang sesat dari jalan-Nya dan Dialah yang lebih mengetahui siapa yang mendapat petunjuk". 15

Beberapa dari ahli tafsir memiliki pendapat dalam menerjemahkan ayat di atas termasuk kata kunci di dalamnya seperti Bilhikmah, Walmau'idhzah hasanah dan Wajadilhum. Bil-Hikmah menurut Quraish Sihab antara lain berarti yang paling utama dari segala sesuatu, baik pengetahuan maupun perbuatan. Hikmah juga berarti sebagai sesuatu yang akan mendatangkan kemaslahatan dan kemudahan yang 
Komunike, Volume XII, No. 2 Desember 2020

besar. ${ }^{16}$ Artinya, segala tindak-tanduk kita tidak terlepas dari aspek kebijaksaan termasuk komunikasi yang seusai dengan kondisi lawan bicara (komunikan) sebagaimana penggalan hadits Rasulullah SAW: Anzilin nasa 'ala qadri 'uqulihim" yang artinya "Bicaralah pada orang lain sesuai dengan kadar kemampuan berpikirnya" kaidah dasar dari beliau ini sekaligus sebagai pengejawantahan keimanan seseorang.

Kemudian istilah

Walmau'idhzah hasanah diartikan sebagai pengajaran yang baik, atau pesan-pesan yang baik, yang disampaikan sebagai nasihat. Dalam Walmau'idhzah hasanah ini mencakup targhib (seruan kearah kebaikan dan balasan kebaikan) dan tarhib (seruan meninggalkan keburukan dengan memberi peringatan dan ancaman bagi mereka yang melanggar). ${ }^{17}$ Konsep ini lebih menegaskan dakwah-bil hal sebagai manifestasi hamba dalam melakukan amal kebaikan dengan memberi

${ }^{16}$ M. Qurasih Shihab, Tafsir Al-Misbah, (Jakarta: Lentera hati, 2002), hlm. 386. pelajaran dan pengajaran yang santun dan moderat.

Terakhir, istilah Wajadilhum menurut Quraish Shihab berasal dari kata jidal yang bermakna diskusi atau bukti-bukti yang mematahkan alasan atau dalih mitra diskusi dan menjadikannya tidak dapat bertahan baik yang dipaparkan itu diterima oleh semua orang maupun hanya mitra bicara. ${ }^{18}$ Bagi peneliti konsep ini tidak hanya sebatas diskusi atau debat melainkan sambil menyeru kepada Islam dengan mengedepankan ilmu dan etika berkomunikasi. Sehingga, ayat dakwah ini memiliki relasi yang kuat terhadap trilogi konsep di atas yaitu Ilmu, Iman dan amal (kognitif, afektif dan psikomotor) pada konteks inovasi dakwah dalam membaca kondisi komunikan (mad'u) sebagai upaya dakwah yang adaptif.

Temuan kajian ini menunjukkan pada bagian spiritual, perguruan tinggi dapat memainkan peran. Sebagaimana dalam kognisi sosial pada orang dewasa, maka

17 Ahmad ibn Muhammad Ash-Shawy, Hasyiyah Ash-Shawy, (Libanon: Dar al-Fikr, 2007), hlm. 412

${ }^{18}$ M. Qurasih Shihab, Tafsir ..., hlm 385 
peguruan tinggi memainkan peran pendidikan dan pengajaran kepada mahasiswa sebagai pelanggan utama. Termasuk dalam kaitan dengan lingkungan yang didiami untuk memberikan

kesempatan memperkaya

kemampuan masyarakat. Perguruan tinggi juga memiliki kesempatan untuk mengembangkan kemampuan sosial masyarakat sekitarnya. Karenanya, keberadaan perguruan iinggi menjadi bagian masyarakat yang dapat menjadi fasilitator pengembangan

masyarakat. Termasuk pada pembentukan lingkungan keagamaan $^{19}$. Tujuan ini tidak saja berkaitan dengan dharma pengabdian masyarakat namun juga berkait dengan instrumen pemberdayaan umat.

Pendidikan tinggi merupakan sarana memperkuat keberagamaan yang mana asing-masing menjadi bagian utama dalam masyarakat yang didiaminya. Sementara lingkungan minoritas justru menjadi tantangan tersendiri. Setiap lembaga berupaya

19 Wekke, I. S., \& Sahlan, A. Strategy in Creating School Environment: Lessons from untuk tetap menjalankan fungsi utama pendidikan tinggi. Pada saat yang sama, memiliki kewajiban untuk selalu pula menjadi bagian dari dakwah di dalam masyarakat secara internal. Artikel ini menunjukkan bahwa ada fungsi ganda yang diemban perguruan tinggi. Unnes berupaya untuk menjalankan mandat pendidikan tinggi sesuai UU Nomor 12 Tahun 2012 dan di saat yang sama tetap berupaya untuk menjalankan misi keagamaan sesuai visinya sebagai universitas berwawasan konservasi. Ragam inovasi dakwah di Unnes yang membedakannya dengan perguruan tinggi lain dapat dikategorikan menjadi dua yaitu yang bersifat rutin formal dan nonrutin informal.

\section{Yang menonjol adalah inovasi pilihan jenis kegiatannya yang beragam dan terjadi di setiap unit kerja/fakultas, yang ini tidak dirasakan di PT lain. Di setiap fakutlas ada kegiatan Fakultas Bersholawat di masing-masing Dies Fakultas nya. Lalu kegiatan Khataman Al Quran yang di adakan di tiap tiap fakultas. Di Pascasarjana diselenggarakan kegiatan khataman rutin setiap selapan}

High Schools in Indonesia. Procedia-Social and Behavioral Sciences. (2014).

Vitradesie dan Andri Kurniawan 203 
Komunike, Volume XII, No. 2 Desember 2020

(35 hari) sekali. Metode dakwah ala pondok pesantren juga menjadi inovasi UNNES. Kegiatan ini terlihat saat pengajian selapanan ahad pahing yang diasuh oleh Gus Lukman Hakim dari Pondok pesantrean azzuhri (MKha_W).

Pendapat informan mendukung pendekatan kontingensi dalam bingkai dakwah kontekstual guna menjawab kebutuhan sivitas akademika dan sekaligus masyarakat (umat). Persoalan yang dihadapi umat tidak hanya dapat diselesaikan hanya dengan mendengar ceramah saja melainkan perlu aksi nyata yang lebih konkrit sebagaimana dilakukan di Unnes (dakwah bil hal).

Hal ini berkaitan dengan hadits Rasulullah SAW yang menjelaskan:

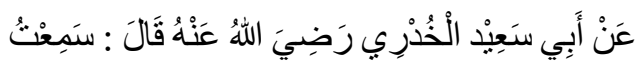

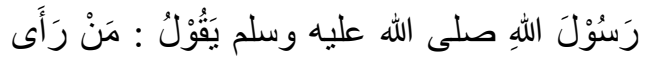

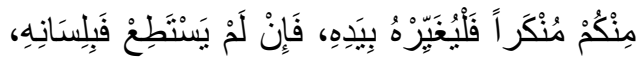

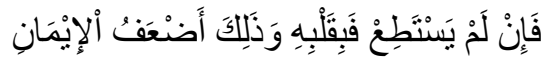

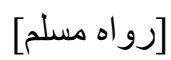

"Dari Abu Sa'id Al Khudri radiyallahuanhu berkata: Saya mendengar Rasulullah shallallahu

${ }^{20}$ Bakr Abdillah Abu Zaid, 40 Hadits Pilihan (Matan Hadits Arba'in), (Solo: At-Tibyan, 2013), hal. 79. 'alaihi wa sallam

bersabda:"Barangsiapa di antara kamu melihat kemungkaran hendaklah dia mencegahnya dengan tangannya. Jika dia tidak sanggup, maka dengan lisannya. Dan jika ia tidak sanggup juga, maka dengan hatinya, dan itu adalah selemahlemahnya iman". (H.R. Muslim). ${ }^{20}$

Pendekatan dakwah bil-lisan dan bil-hal pada hadits Rasulullah SAW di atas menunjukkan harmonisasi di antara keduanya. Konsep ini secara tegas dijelaskan dengan istilah biyadihi sebagai dakwah tranformatif dalam menginternalisasikan nilai-nilai Islam dalam kehidupan sosial melalui tindakan aplikatif sekaligus mampu menyampaikannya dalam bentuk verbal (konvensional) yang terkandung dalam istilah fabilisanihi dalam hadits tersebut.

Kontekstualisasi ajaran dan nilai Islam dalam kehidupan masyarakat adalah salah satu jalan dakwah. Unnes menyadari bahwa 
dakwah tidak hanya dapat dipahami secara lisan semata (retorika), namun harus sampai menuju kepada konsepsi riil (kontekstual) memecahkan problematika umat yang kian hari kian kompleks mulai dari problematika pendidikan, ekonomi, sosial dan budaya bahkan sekarang dengan terbukanya ekspresi keberagaman telah melahirkan problematika baru di kalangan umat yaitu radikalisasi dan liberalisasi paham keagamaan.

Informan lain menyatakan bahwa inovasi dakwah dicirikan oleh gerakan moderasi berkemajuan. Unnes berpendapat bahwa menjadikan inovasi dakwah sebagai budaya organisasi akan dapat menyentuh sisi terdalam manusia menggunakan pendekatan agama.

Dakwah annahdliyyah yang dilakukan komunitas Aswaja UNNES berdasarkan prinsip $N U$ yang selalu menjalankan prinsip tawasuth (moderat), tawazun (seimbang), tasamuh (toleran) serta amar makruf nahi munkar, menjadikan konsep merangkul dan tidak memusuhi (AM_W).

$$
\begin{aligned}
& \text { Inovasinya berupa kajian } \\
& \text { keagamaan } \\
& \text { pengelolaan ZIS secara modern }
\end{aligned}
$$

dan profesionàl (penggunaan akuntansi ZIS berbasis teknologi informasi, laporan keuangan rutin, pemberian beasiswa, santunan, sembako di masa Covid 19, dll)(MKho_W)

Para pihak yang dikatakan berkontribusi penting dalam menyuburkan ghirah dan menciptakan inovasi dakwah dapat dikategorikan menjadi langsung:

Pengelola/takmir masingmasing masjid di lingkungan Unnes. Khusus di Masjid Ulil Albab

(http://masjid.unnes.ac.id/) ada Badan Amalan Islam ketuanya pak Anwar Haryono. Untuk LAZIZ

(https://lazis.unnes.ac.id/) ketuanya pak Edy Purwanto (Mkho_W).

dan tidak langsung:

$\begin{array}{lr}\text {...jamiyyah } & \text { Komunitas } \\ \text { Ahlussunnah wal jama'ah } \\ \text { UNNES }\left(A M_{-} W\right) .\end{array}$

Perihal pendanaan dakwah, Unnes memiliki mekanisme formal yang mendukung syiar Islam.

$\begin{array}{lr}\text { Unnes relatif } & \text { kecil } \\ \text { mengalokasikan anggaran } & \text { hecara khusus, ranya } \\ \text { menyerahkan pengelolaan dana } \\ \text { ZIS pegawai ke LAZIZ dan } \\ \text { bantuan hewan kurban. Selain } \\ \text { itukegiatan merekadidanaidari } \\ \text { kas masjid masing-masing. } \\ \text { Dengan model pendanaan }\end{array}$


Komunike, Volume XII, No. 2 Desember 2020

seperti itu kegiatan syiar tetap bisa jalan dengan baik (Mkho_W).

Selanjutnya, dalam konteks sosial, radikalisasi telah melahirkan suasana yang tidak nyaman antar sesama umat Islam, saling mencurigai, saling sesat menyesatkan serta memperebutkan kesalehan spiritual di mata Tuhan. Takmir masjid di tiap fakultas juga senantiasa meningkatkan kewaspadaan penyebaran paham radikal intoleran serta memberikan pembelajaran literasi digital kepada mahasiswa dan generasi di lingkungan kampus dan masyarakat. Upaya ini bertujuan melindungi mahasiswa dan generasi muda dari penyebaran paham radikal intoleran yang pergerakannya dilakukan secara masif dan lembut melalui secara langsung melalui pertemanan/indoktrinasi dan secara tidak langsung melalui jejaring media sosial.

\section{E. SIMPULAN}

Integrasi dan interkoneksi Ilmu Dakwah dengan sains sosial dibangun berdasarkan izdiwaju ulumil Islami yang bersumber dari nash, ilmu-ilmu sosial dan filsafat serta praktik terbaik kehidupan beragama yang mengedepankan pendekatan kontingensi. Ketiga bidang tersebut dinamakan ilmu-ilmu Islam. Pada konteks inovasi dakwah di Unnes, izdiwaj menghasilkan Ilmu Dakwah yang integratif seperti Psikologi Dakwah, Sosiologi Dakwah, Manajemen Dakwah yang diterapkan pada saat menyusun program-program rutin untuk meningkatkan ghirah dan kecintaan pada agama Islam.

$$
\text { Adapun izdiwaj ekonomi }
$$
dengan syariah melahirkan Ekonomi Syariah yang diterapkan dalam wujud aktivitas sosial (yaitu pemberian beasiswa mulai tingkat SD hingga perguruan tinggi bagi mahasiswa Unnes maupun masyarakat sekitar) maupun aktivitas komersial (yaitu pendanaan ekonomi produktif untuk wirausaha berpotensi syariah). 
Penulis menyajikan saran bagi regulator yaitu pimpinan perguruan tinggi lain dan Kemendikbud dalam bentuk pendekatan institusional dan inkrimental. Merujuk pendapat ${ }^{21}$ pendekatan institusional dapat berjalan dengan berbagai mekanisme: 1) coersif isomorphis yang mana perguruan tinggi mengambil beberapa bentuk atau melakukan adopsi terhadap perguruan tinggi lain karena tekanan-tekanan dari dalam organisasi atau masyarakat yang lebih luas; 2) mimesis isomorphis, yaitu imitasi sebuah perguruan tinggi oleh perguruan tinggi lain. Mimesis sebagai solusi karena organi sasi lemah, tidak memiliki kreativitas dan profesionalitas; dan 3) normatif isomorphis, karena adanya tuntutan professional dan perguruan tinggi mampu mengembangkan model sendiri setelah mengkaji beberapa bentuk dari organisasi lain. Pendekatan inkrimental atau dikenal dengan tambal sulam dalam organisasi. Pendekatan ini menjadi solusi bagi perguruan tinggi yang telah memiliki inovasi dakwah sendiri dan masih membutuhkan perbaikan. Karenanya, adopsi beberapa nilai dari luar perguruan tinggi dianggap penting dan melupakan nilai lain yang dianggap kurang penting. 
Komunike, Volume XII, No. 2 Desember 2020

\section{F. DAFTAR PUSTAKA}

Wahid, Abdurrahman 2001. Pergulatan Negara, Agama, dan Kebudayaan. Jakarta: Desantara.

Ahmad Ibn Muhammad Ash-Shawy, 2007, Hasyiyah Ash-Shawy, Libanon: Dar al-Fikr.

Andri Kurniawan. (2020). Peran Masjid sebagai Sentra Dakwah Moderasi. Jurnal Komunikasi Islam, 10(1), 125-145. https://doi.org/10.15642/jki.20 20.10.1.125-145

Asep Iwan Setiawan, 2011, Efektivitas Dakwah Fi'ah: Studi Model Dakwah Pada Lembaga Dakwah Kampus, Jurnal Ilmu Dakwah, Vol. 5 No. 2.

Bakr Abdillah Abu Zaid, 2013, 40 Hadits Pilihan (Matan Hadits Arba'in), Solo: At-Tibyan.

Blakemore, S.-J. 2008. Development of The Social Brain During Adolescence.

Quarterly Journal of Experimental Psychology. Vol. 61, No. 1: 409.

Contessi, N. P. 2015. Central Asia in Asia: Charting Growing TransRegional Linkages. Journal of Eurasian Studies. Vol. 7, No. 1, 3-13.

Cresswell, JW 2007, Qualitative Inquiry and Research Design: Choosing Among Five Traditions, 2nd ed., Sage, Thousand Oaks, CA.
Daft, R. L. (2014). Management. South-Western Cangage Learning.

Denzin, N. K., \& Lincoln, Y. S. 2002. The qualitative inquiry reader. Sage.

Griffin, R. W. 2016. Management. Nelson Education.

I. S. Wekke, \& Sahlan, A. 2014. Strategy in Creating School Environment: Lessons from High Schools in Indonesia. Procedia-Social and Behavioral Sciences.

Kementeriaan Agama RI, Al-Qur'an Al-Karim dan Terjemahnya.

Kirk, J., Miller, M. L., \& Miller, M. L. 1986. Reliability and validity in qualitative research (Vol. 1). Sage.

Nizar Ali, Pengembangan Paradigma Keilmuan IntegrasiInterkoneksi STAIN-IAIN Padang sidimpuan. Makalah disampaikan pada Studium Genaral Mahasiswa Baru STAIN Padangsidimpuan Tahun 2013.

Peters, L. H., Hartke, D. D., \& Pohlmann, J. T. (1985). Fiedler's Contingency Theory of Leadership: An application of the meta-analysis procedures of Schmidt and Hunter. Psychological bulletin, 97(2), 274.

Rahmat, I. (2016). The Celestial Management: Ikhtiar Mewujudkan Budaya Organisasi Islam. Jurnal $M D, 2(1)$. 
Komunike, Volume XII, No. 2 Desember 2020

Robbins, S. P., Stuart-Kotze, R., \& Coulter, M. (2000). Management.

Scarborough, Ont.: Prentice Hall Canada.

Siti Maisaroh, 2019, Dakwah Kultural Perguruan Tinggi Islam Pada Mahasiswa Nonmuslim (Studi: Sekolah Tinggi Ilmu Ekonomi (STIE) Yapis Merauke", Tesis, Pascasarjana UIN Sunan Kalijaga, Yogyakarta. Cognition in Adolescence: Social Rejection and Theory of Mind. Psicología Educativa. Volume 21, Nomor 2: 125-131

Shihab, M. Quraish. 2002, Tafsir AlMisbah, Jakarta: Lentera hati.

Extra News, "BNPT Road Show Ke Poltek Sriwijaya", dalam https://extranews.id/2019/10/ o1/bnpt-road-show-ke-poltek sriwijaya-cegah-radikalismel diakses 23 November 2020 